\title{
Lysosomal dysfunction in TMEM106B hypomyelinating leukodystrophy
}

Yoko Ito, PhD, Taila Hartley, MSc, Stephen Baird, PhD, Sunita Venkateswaran, MD, Cas Simons, PhD, Nicole I. Wolf, MD, PhD, Kym M. Boycott, PhD, MD, David A. Dyment, DPhil, MD,*

and Kristin D. Kernohan, $\mathrm{PhD}^{*}$

Neurol Genet 2018;4:e288. doi:10.1212/NXG.0000000000000288

Transmembrane protein 106B (TMEM106B; NM 001134232) was recently identified as a gene responsible for a form of hypomyelinating leukodystrophy (HLD) ${ }^{1,2}$ All 5 cases identified to date carry the identical c.754 G > A, (p.Asp252Asn) mutation. ${ }^{1,2}$ Although the exact function is unknown, ${ }^{3}$ studies of TMEM106B in the context of frontotemporal lobar degeneration with 43-kD TAR DNA-binding protein (TDP-43) pathology (FTLD-TDP) indicate that TMEM106B likely acts as a lysosomal regulator and can modify risk for FTLD-TDP. ${ }^{4}$ However, the molecular effects of the (p.Asp252Asn) substitution have not yet been reported for TMEM106B-associated HLD. The HLDs are heterogeneous conditions, with the known disease genes playing roles in myelin sheath structure (e.g., PLP1) and other cellular functions that are not oligodendrocyte specific, including protein translation, molecular chaperoning, and cytoskeletal regulation. ${ }^{5}$ We set out to assess if this recurrent TMEM106B substitution was affecting lysosome biology or had an alternate role underlying the HLD pathogenesis. Implication of lysosome biology in HLD provides exciting new advances in our understanding of the molecular underpinnings of this condition and the complexities of neurodevelopment.

\section{Functional analysis}

Using patient-derived fibroblasts (patient 4), ${ }^{1}$ we assessed TMEM106B messenger RNA (mRNA) and protein levels and found that these were unaltered in patient cells compared with controls (figure, A). TMEM106B has been shown to affect lysosome number, morphology, and acidification. ${ }^{4,6}$ LAMP1 staining, which marks lysosomes, showed an increase in the number of lysosomes in patient fibroblasts compared with controls, although the average size of the lysosome remained unchanged (figure, B). Staining with a $\mathrm{pH}$-sensitive fluorescent dye showed that despite the increased number of lysosomes, a substantial decrease in the number of lysotracker-positive foci was observed, indicating that patient lysosomes show impaired acidification (figure, B).

Impairment in lysosomal acidification can affect the processing and function of lysosomal enzymes. Therefore, we next examined the levels of cathepsin B, cathepsin L, and dipeptidyl peptidase VII (DPP7) as these are lysosomal proteases previously shown to be decreased in Tmem106b null mice. ${ }^{6}$ The (p.Asp252Asn) variant results in a decrease in the mature form of cathepsin B protein and, importantly, a concomitant decrease in the activity levels of this enzyme in patient cells (figure, $\mathrm{C}$ and $\mathrm{D}$ ). This reduction is predicted to not only affect the degradation of cathepsin $\mathrm{B}$ protein substrates but also the regulation of the T-cell transcription factor (TFEB). ${ }^{7}$ As cathepsin B suppresses lysosomal number in a TFEB-dependent manner, ${ }^{7}$ it is likely that the reduction in cathepsin $\mathrm{B}$ activity contributes to the increased lysosome number observed. Patient cells also displayed an accumulation of both intermediate and mature forms of cathepsin L and no change in DPP7 levels (figure, C, data not shown). Taken together,
Correspondence

Dr. Dyment

ddyment@cheo.on.ca

\footnotetext{
*These authors contributed equally to this work as senior author.
}

From the Children's Hospital of Eastern Ontario Research Institute (Y.I., T.H., S.B., K.M.B., D.A.D., K.D.K.), Ottawa, Ontario, Canada; Division of Neurology (S.V.), Children's Hospital of Eastern Ontario, Ottawa, Ontario, Canada; Institute for Molecular Bioscience (C.S.), University of Queensland, St. Lucia, Queensland, Australia; and Department of Child Neurology (N.I.W.), VU University Medical Center, and Amsterdam Neuroscience, Amsterdam, The Netherlands.

Funding information and disclosures are provided at the end of the article. Full disclosure form information provided by the authors is available with the full text of this article at Neurology.org/NG.

The Article Processing Charge was paid for by Genome Canada and CIHR.

This is an open access article distributed under the terms of the Creative Commons Attribution-NonCommercial-NoDerivatives License 4.0 (CC BY-NC-ND), which permits downloading and sharing the work provided it is properly cited. The work cannot be changed in any way or used commercially without permission from the journal. 
A

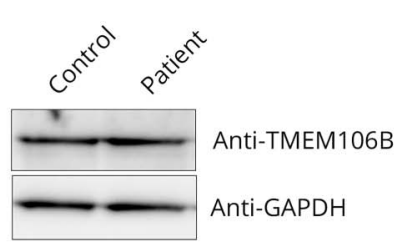

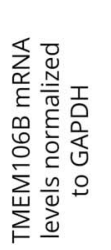

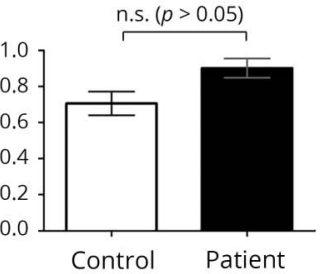

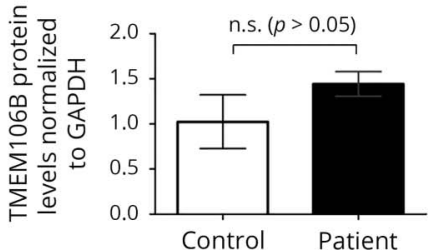

B
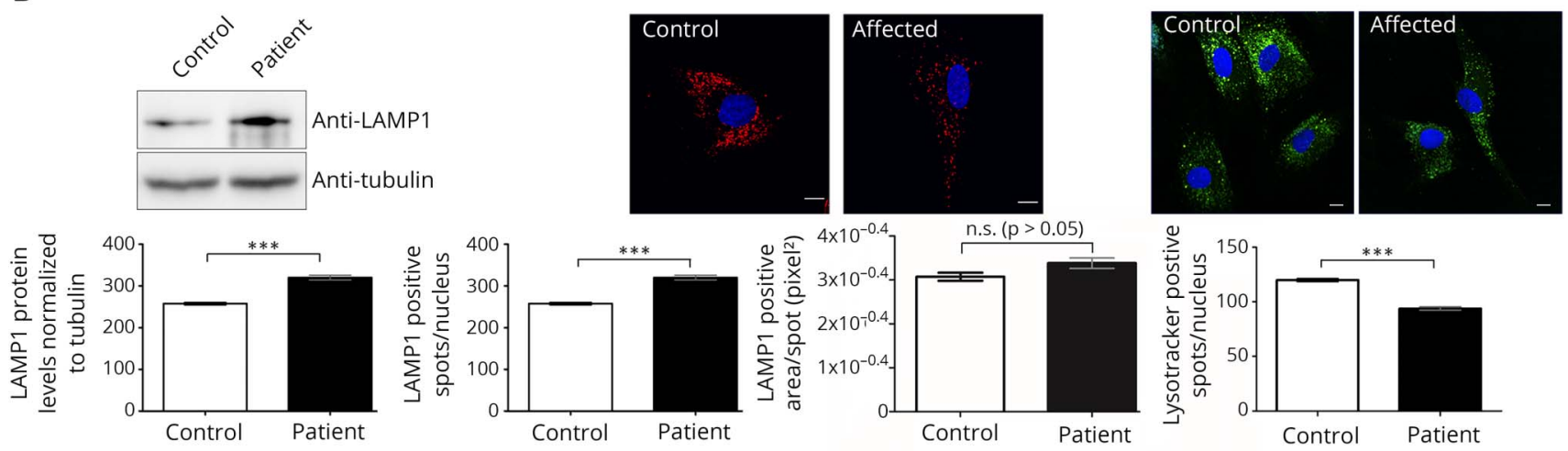

C Anti-cathepsin B Anti-cathepsin L

D
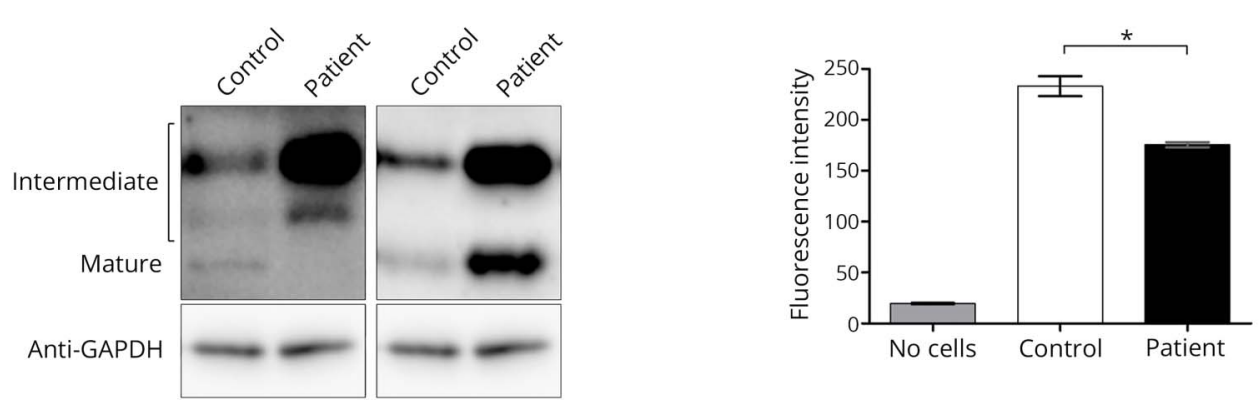

(A) Control and patient fibroblasts had comparable levels of both mRNA and TMEM106B protein when examined by real-time quantitative PCR and western blot analysis, respectively ( $p>0.05$, 2-tailed Student's $t$-test). (B) An increase in the lysosome-specific marker LAMP1 was observed in patient cells by both Western blot analysis and immunofluorescent staining $(p<0.001$, 2-tailed Student's $t$-test). (A substantial decrease was observed in the number of lysotrackerpositive spots in the patient cells by immunofluorescence; $p<0.001$, 2-tailed Student's $t$-test.) For immunofluorescent studies, fibroblast images were collected from 10 wells per sample from 3 independent experiments using the Opera High Content Screening System (Perkin Elmer) and analyzed using Columbus software. Scale bars represent $10 \mu \mathrm{m}$. Three control fibroblast cell lines were used for these studies. (C) Western blot analyses showed an accumulation of the intermediate forms of both cathepsin B and cathepsin $L$, but accumulation of only the mature form of cathepsin $L$ in patient fibroblasts. The mature form of cathepsin B is not detectable by Western blot analysis in patient cells. (D) A fluorescence-based enzyme assay shows reduction in the activity of cathepsin $B$ in affected fibroblasts $(p<0.05,1$-way analysis of variance, Bonferroni post-test).

these results show that the (p.Asp252Asn) substitution affects multiple aspects of lysosome biology.

\section{Discussion}

TMEM106B is a structural component of the lysosomal membrane and, importantly, plays a role in lysosome acidification. ${ }^{6}$ The acidity of the lysosome is important to mediate multiple aspects of lysosomal function, including maintaining active lysosome enzymes, directing the maturation of endosomes, and maintaining intralysosomal calcium levels. ${ }^{8}$
Therefore, impaired acidification in our patient cells is predicted to have noteworthy implications for lysosome function. Lysosomes are required for the generation of myelin during the development of the CNS. Notably, this includes trafficking of PLP1 protein, the main component of myelin, from the late endosome/lysosome to the cell membrane for exocytosis in oligodendrocytes. ${ }^{8}$ In addition, disruption of endosomelysosome biogenesis caused by mutations in another lysosomal-associated gene, vacuolar protein sorting 11, causes another form of HLD. Tmem $106 b$ null mice are phenotypically normal, and numerous loss-of-function variants in TMEM106B are reported in the gnomAD database, 
supporting a non-haploinsufficiency mechanism underlying TMEM106B-related HLD. Further studies are required to elucidate the specific dominant negative or gain-of-function effect of the (p.Asp252Asn) mutation that results in decreased lysosomal acidification. Also, potential effects on other HLD-related proteins, such as PLP1, which would have direct consequences on myelin formation need to be examined. We appreciate that these experiments are based on a sample from a single individual and that additional studies from other (p.Asp252Asn)-positive individuals are necessary to confirm these findings. Nevertheless, this report provides an important first step in defining the role of TMEM106B in lysosome function in HLD. TMEM106B now joins the catalogue of essential lysosomal proteins implicated in human neurologic disease.

\section{Author contributions}

Y. Ito: study concept and design, acquisition, analysis, and interpretation of data, and manuscript preparation. T. Hartley: critical revision of manuscript for intellectual content. S. Baird: acquisition of data and critical revision of manuscript for intellectual content. S. Venkateswaran: critical revision of manuscript for intellectual content. C. Simons: critical revision of manuscript for intellectual content. N.I. Wolf: critical revision of manuscript for intellectual content. K.M. Boycott: critical revision of manuscript for intellectual content. D.A. Dyment: analysis and interpretation of data, manuscript preparation, and study supervision. K.D. Kernohan: analysis and interpretation of data, manuscript preparation, and study supervision.

\section{Acknowledgments}

The authors would like to thank the patient and family; without whom this work would not be possible. The authors also wish to acknowledge Dr. Wendy Mears for her tissue culture expertise. This work was supported by the Care4Rare Canada Consortium funded by Genome Canada, the Canadian Institutes of Health Research, the Ontario Genomics Institute, Ontario Research Fund, Génome Québec, and the Children's Hospital of Eastern Ontario Foundation.

\section{Study funding}

This work was performed under the Care4Rare Canada Consortium funded by Genome Canada, the Canadian Institutes of Health Research, the Ontario Genomics Institute, Ontario Research Fund, Génome Québec, and Children's Hospital of Eastern Ontario Foundation.

\section{Disclosure}

Y. Ito, T. Hartley, S. Baird, S. Venkateswaran, and C. Simons report no disclosures. N.I Wolf has served on scientific advisory boards for European Leukodystrophy Association (ELA) and Mission Massimo Foundation (both without compensation); has received travel funding from ELA; has served on the editorial boards of Neuropediatrics and Neurology; has received research support from Hersenstichting, Metakids, the Stofwisselkracht Foundation, the M.O. Knip Foundation, and Yasho's Leukodystrophy Foundation; and holds stock/ stock options in Aer Beatha. K.M. Boycott, D.A. Dyment, and K.D. Kernohan report no disclosures. Full disclosure form information provided by the authors is available with the full text of this article at Neurology.org/NG.

Received by Neurology March 23, 2018. Accepted in final form August 21, 2018.

\section{References}

1. Simons C, Dyment D, Bent SJ, et al. A recurrent de novo mutation in TMEM106B causes hypomyelinating leukodystrophy. Brain 2017;140:3105-3111.

2. Yan H, Kubisiak T, Ji H, Xiao J, Wang J, Burmeister M. The recurrent mutation in TMEM106B also causes hypomyelinating leukodystrophy in China and is a CpG hot spot. Brain 2018;141:e36.

3. Nicholson AM, Zhou X, Perkerson RB, et al. Loss of Tmem106b is unable to ameliorate frontotemporal dementia-like phenotypes in an AAV mouse model of C9ORF72 -repeat induced toxicity. Acta Neuropathol 2018;6:1-14.

4. Nicholson AM, Rademakers R. What we know about TMEM106B in neurodegeneration. Acta Neuropathol 2016;132:639-651.

5. Pouwels PJW, Vanderver A, Bernard G, et al. Hypomyelinating leukodystrophies: translational research progress and prospects. Ann Neurol 2014;76:5-19.

6. Klein ZA, Takahashi H, Ma M, et al. Loss of TMEM106B ameliorates lysosomal and frontotemporal dementia-related phenotypes in progranulin-deficient mice. Neuron 2017;95:281-296.e6.

7. Man SM, Kanneganti TD. Regulation of lysosomal dynamics and autophagy by CTSB/cathepsin B. Autophagy 2016;12:2504-2505.

8. Shen Y, Yuan Y, Su W, Gu Y, Chen G. The roles of lysosomal exocytosis in regulated myelination. J Neurol Neuromed 2016;1:4-8. 


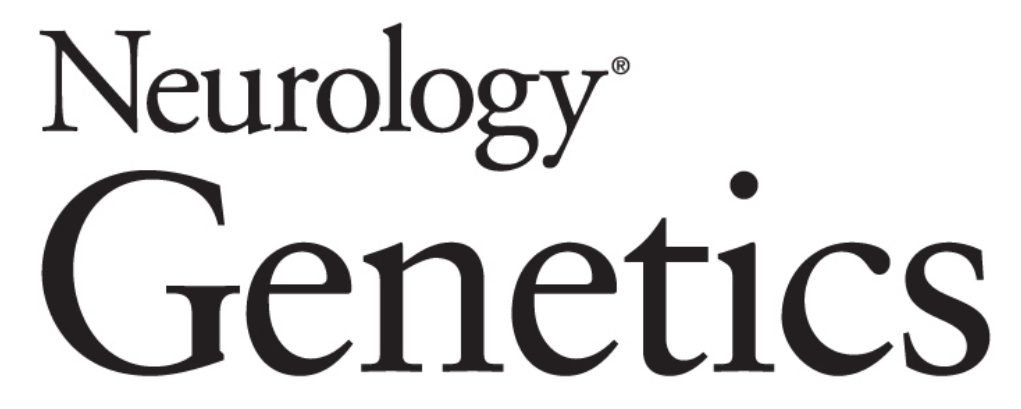

\section{Lysosomal dysfunction in TMEM106B hypomyelinating leukodystrophy Yoko Ito, Taila Hartley, Stephen Baird, et al. \\ Neurol Genet 2018;4; \\ DOI 10.1212/NXG.0000000000000288}

This information is current as of November 13, 2018

\section{Updated Information \& Services}

References

Subspecialty Collections

Permissions \& Licensing

Reprints including high resolution figures, can be found at: http://ng.neurology.org/content/4/6/e288.full.html

This article cites 8 articles, 0 of which you can access for free at: http://ng.neurology.org/content/4/6/e288.full.html\#\#ref-list-1

This article, along with others on similar topics, appears in the following collection(s):

All Demyelinating disease (CNS)

http://ng.neurology.org//cgi/collection/all_demyelinating_disease_cns Frontotemporal dementia

http://ng.neurology.org//cgi/collection/frontotemporal_dementia Gene expression studies

http://ng.neurology.org//cgi/collection/gene_expression_studies Leukodystrophies

http://ng.neurology.org//cgi/collection/leukodystrophies

Information about reproducing this article in parts (figures,tables) or in its entirety can be found online at:

http://ng.neurology.org/misc/about.xhtml\#permissions

Information about ordering reprints can be found online: http://ng.neurology.org/misc/addir.xhtml\#reprintsus

Neurol Genet is an official journal of the American Academy of Neurology. Published since April 2015, it is an open-access, online-only, continuous publication journal. Copyright Copyright $\odot 2018$ The Author(s). Published by Wolters Kluwer Health, Inc. on behalf of the American Academy of Neurology.. All rights reserved. Online ISSN: 2376-7839.

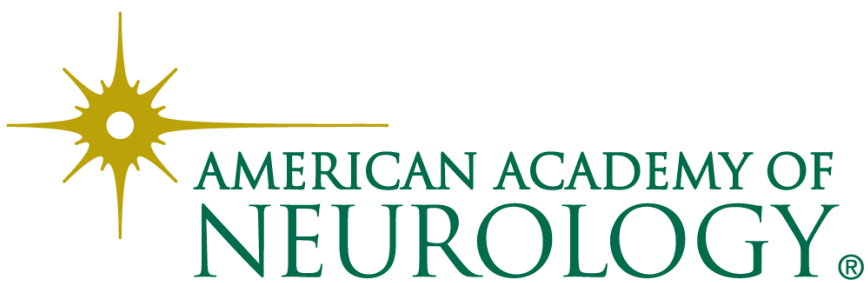

